\title{
Mulheres imigrantes: presença e ocultamento (interiores de São Paulo, 1880-1930)
}

\author{
Maria Izilda Santos Matos \\ Oswaldo Truzzi ${ }^{\star \star}$ \\ Carla Fernandes Conceição $0^{\star \star \star}$
}

\begin{abstract}
Este artigo procura recuperar a presença feminina no processo de e/imigração para o interior do estado de São Paulo, abordando aspectos diferenciados das experiências, ações cotidianas, atividades de trabalho e background cultural das mulheres imigrantes. Para tal, valorizam-se o uso e a releitura de certa diversidade de fontes que incluem cartas, prontuários, depoimentos, memórias, imprensa diária e operária, fontes empresariais e registros censitários, entre outras. 0 texto procura contextualizar o protagonismo da mulher imigrante tanto no meio rural paulista, marcado pela expansão da cafeicultura, quanto nas cidades interioranas, nas quais sua presença nos ofícios urbanos, no comércio, na indústria e nos afazeres domésticos é marcante. Propõe-se ainda abrir horizontes metodológicos para os estudos dos deslocamentos, questionando o imigrante universal masculino e destacando a importância de se observar a experiência migratória a partir de outros olhares, inclusive o feminino.
\end{abstract}

Palavras-chave: Mulheres. Imigrantes. Gênero. Interior paulista.

\footnotetext{
* Pontifícia Universidade Católica de São Paulo (PUC-SP); Conselho Nacional de Desenvolvimento Científico e Tecnológico (CNPq), São Paulo-SP, Brasil (mismatos@pucsp.br; https://orcid.org/0000-0003-1565-2995).

** Universidade Federal de São Carlos (UFSCar); Conselho Nacional de Desenvolvimento Científico e Tecnológico (CNPq), São Carlos-SP, Brasil (truzzi@ufscar.br; https://orcid.org/0000-0002-9046-5092).

*** Universidade Federal de São Carlos (UFSCar), São Carlos-SP, Brasil (carlafcon@gmail.com; https://orcid.org/00000003-1565-2995).
} 


\section{Introdução}

No Brasil, o tema da imigração concentra uma produção ampla, diversificada e enriquecida por abordagens que analisam aspectos diferenciados da questão. No caso paulista, a imigração pode ser considerada uma temática eleita pela historiografia, particularmente quando intercruzada com outras questões privilegiadas como os estudos sobre a cafeicultura, indústria, trabalho e movimento operário. Apesar desse privilegiamento, as experiências migratórias femininas têm sido pouco analisadas, permanecendo a tendência à observação dos fluxos sob a perspectiva universal masculina. Este artigo procura dar visibilidade à presença feminina no processo de e/imigração para o interior do estado de São Paulo, abordando aspectos diferenciados das experiências, ações cotidianas, atividades de trabalho e background cultural das mulheres imigrantes.

\section{Tema e historiografia: imigração, interiores e mulheres}

Entre 1882 e 1934, dos quase quatro milhões de imigrantes que entraram no Brasil, cerca de $60 \%$ se instalaram no estado de São Paulo, atraídos pela demanda crescente de braços para a cafeicultura e outras possibilidades. Grande parte desses imigrantes veio subsidiada e era dirigida para os interiores do estado, destacando-se inicialmente os italianos; contudo, após o Decreto Prinetti, sancionado em 1902 e que proibiu a vinda de italianos com passagens subsidiadas (ALVIM, 1986; TRENTO, 1989; VANGELISTA, 1991; TRUZZI, 2016; MATOS, 2013), as entradas desta nacionalidade diminuíram, sendo compensadas pelo aumento das chegadas dos portugueses e espanhóis e, posteriormente, dos japoneses. ${ }^{1} \mathrm{~A}$ maioria desses imigrantes que foram para os interiores acompanhou a expansão cafeeira e ferroviária em direção ao oeste do estado. ${ }^{2}$

Prefere-se aqui o uso de "interiores", no plural, justamente para enfatizar a heterogeneidade de situações e do meio social nos quais as mulheres atuaram como protagonistas fora da capital paulista, especialmente no oeste cafeeiro. A própria história da expansão do café, com sua marcha interior adentro do estado, impôs uma dinâmica que desenvolveu regiões distintas em épocas também distintas. Após percorrer o Vale do Paraíba, a cultura se estabeleceu polarizada pela região de Campinas em meados do século XIX e, a partir de então, ganhou novas áreas de expansão incentivadas pela implantação dos eixos ferroviários da Mogiana, em direção a Ribeirão Preto (norte do estado e Minas Gerais), e da Paulista, em direção ao centro. Ao longo das décadas seguintes, São Paulo consolidaria sua malha ferroviária que cobriria toda a extensão de seu território até as margens dos

\footnotetext{
${ }^{1}$ Em 1904, a Espanha também proibiu a vinda de imigrantes subsidiados para o Brasil e tornou ilegal as atividades dos ganchos. Para enfrentar esta situação foram aperfeiçoadas estratégias para manter as saídas: os andaluzes passaram a partir por Gibraltar e os galegos pelo porto de Leixões, em Portugal (MARTíNEZ,1999).

${ }^{2}$ Estima-se que, dos quase 2.250 .000 imigrantes entrados no estado entre 1890 e 1930 , cerca de $58 \%$ foram financiados e em sua maioria passaram pela Hospedaria dos Imigrantes. Nove em cada dez imigrantes saídos desta Hospedaria foram encaminhados para os interiores do estado. Segundo o censo de 1920, dos mais de 1,5 milhão de imigrantes no país, 53\% estavam no estado de São Paulo, destes mais de 800 mil habitavam fora da capital (BASSANEZI et al., 2008).
} 
rios Paraná e Grande. A inserção laboral feminina obviamente acompanhou tal expansão, de modo que, ao longo deste texto, faz-se menção - a título de exemplos (e não com fins de abarcar a totalidade das situações) - a regiões bastante distintas do interior paulista e a setores também bastante distintos nos quais as mulheres estiveram presentes, desde o colonato até as atividades industriais desenvolvidas em alguns municípios.

Neste intenso processo de deslocamento, não houve um padrão único, sendo marcado por toda uma complexidade de situações vivenciadas: muitos imigrantes eram chefes de família, vieram antes de seus familiares que ficaram aguardando pela reunificação familiar; em outros casos, a família veio junta, mas nem todos permaneceram unidos no novo contexto; outros chegaram sós ainda jovens e aqui constituíram novas relações familiares.

FIGURA 1

Passaporte português (1922) - Acervo Arquivo Museu da Imigração/SP

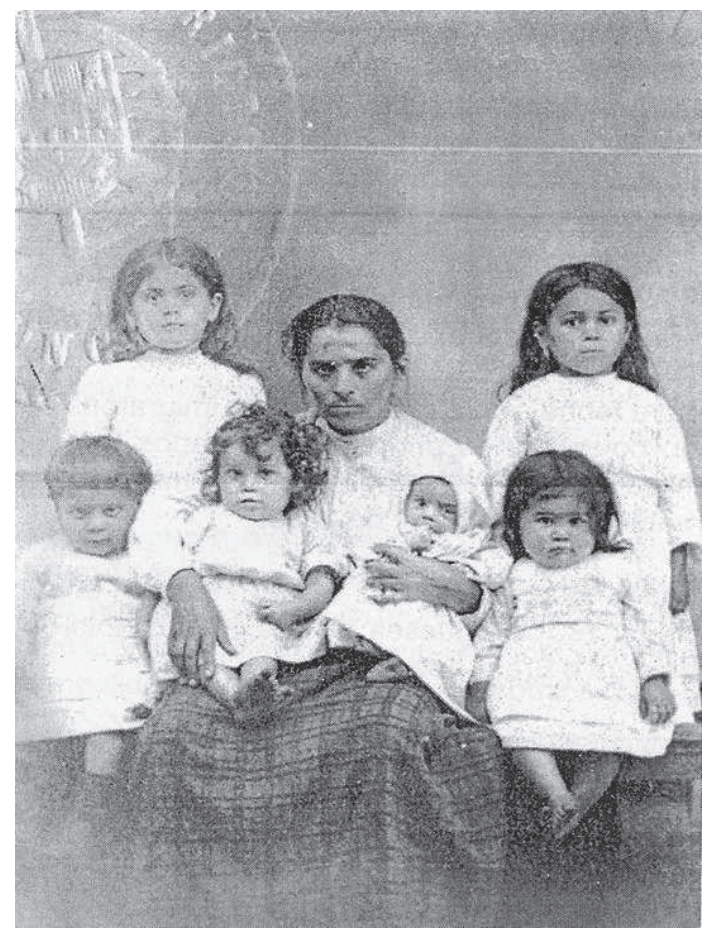

A pouca atenção dada às experiências femininas nos estudos dos processos de e/imigração tendeu a ser justificada pela menor porcentagem de mulheres nos dados oficialmente computados, o que por si só deve ser relativizado. Se algumas experiências de deslocamentos foram a princípio prioritariamente masculinas, o contingente feminino cresceu gradativamente, podendo-se verificar um aumento no número de mulheres casadas, devido à ampliação das entradas em família (priorizadas pelos subsídios do governo paulista) e ações variadas de reconstituição familiar. Dessa forma, esposas, mães, filhas, noras e sogras, sós ou em companhia das famílias, se deslocaram na procura por trabalho, 
independência, casamento, também para fugir das dificuldades cotidianas e na busca por melhores condições de vida, para si e para todos os seus (BASSANEZI, 2012).

Quase sempre silenciadas, as mulheres - partissem ou não - eram atuantes nos processos de deslocamento. Mesmo quando estavam destinadas a permanecer na terra natal, participavam ativamente de todos os procedimentos, bem como das decisões a serem tomadas (quem devia partir, quando, para onde e com quais recursos), incluindo sua atuação nos rituais de partida e nos preparativos para a viagem, além de vir a assumir responsabilidades que antes eram incumbência dos homens.

As saídas dos homens afetavam diretamente o cotidiano feminino, ampliando o trabalho e os encargos das mulheres, que, além das atividades domésticas e cuidados dos filhos, passavam a arcar com a manutenção das propriedades, comércios, negócios incluindo o gerenciamento das finanças familiares. Dessa forma, além das funções tradicionais, elas geriam bens, administravam o uso das remessas, assumiam as lides no comércio e no campo (lavravam, cavavam, colhiam, preparavam os produtos e cuidavam das criações e seus subprodutos), além de outras atividades indispensáveis para a sobrevivência, como apanhar lenha para si e para vender (a padarias e olarias) e realizar trabalhos de fiação e tecelagem (em linho e lã).

Na sociedade de acolhimento, as mulheres imigrantes tiveram seu cotidiano marcado pelo trabalho: foram atuantes no trabalho nas fazendas, núcleos coloniais, estabelecimentos comerciais, fabris e em múltiplas outras atividades, operando também por meio de várias estratégias de sobrevivência. Cercadas de invisibilidades, elas emergem, inevitavelmente, sempre que a névoa que as encobre é dissipada, revelando toda sua capacidade de reinvenção, essencial para o sucesso da empreitada de e/imigração.

Desvendar essas histórias torna-se um desafio de pesquisa: diante da marginalização da mulher na maior parte da bibliografia e documentação oficial, suas experiências, vidas e expectativas necessitam ser recuperadas por meio de um processo constante de investigação, contribuindo para reverter enraizamentos impostos pela historiografia e transformando as mulheres em agentes históricos. ${ }^{3}$

Tendo em vista que as fontes priorizadas pela historiografia envolvem discursos universais que silenciam as mulheres, enfrenta-se o desafio de realizar uma pesquisa documental e bibliográfica, a partir de novos focos da investigação, que valorizam toda uma diversidade de referências. Assim, as fontes utilizadas na escritura dessas histórias do feminino não se resumem a documentos produzidos, "guardados" ou arquivados,

\footnotetext{
${ }^{3}$ As novas abordagens históricas possibilitaram uma abertura para os estudos sobre as mulheres, cabendo destacar a expansão dos estudos do cotidiano que permitiram um questionamento sobre as transformações da sociedade, o funcionamento da família, o papel da disciplina, o significado dos fatos, lutas e gestos, dando visibilidade às experiências femininas. Assim, a expansão dos estudos sobre a mulher vinculou-se a uma redefinição do político, diante do deslocamento do campo do poder das instituições públicas e do Estado para a esfera do privado e do cotidiano, permitindo também o questionamento da universalidade do discurso histórico. Preocupações de abrir trilhas renovadoras, promover a descentralização dos sujeitos históricos e permitir a descoberta das "histórias de gente sem história", focalizando experiências de agentes aos quais se negaram lugar e voz dentro do discurso histórico convencional, integraram aos estudos históricos as experiências femininas frequentemente ignoradas ou mencionadas apenas de passagem (MATOS, 2015).
} 
implicando estratégias metodológicas de questionamento de silêncios e esquecimentos encerrados nas entrelinhas.

Ao desafio de lidar com uma diversidade de situações e de fontes, soma-se o exercício de cruzar, examinar e interpretar exaustiva e continuamente os documentos e escritos. Desvelar experiências do passado requer sempre a paciente busca de indícios, sinais e sintomas, aliada a uma leitura que seja capaz de esmiuçar o explícito como forma de dar sentido ao implícito e ao oculto, por meio de uma relação dialógica que possa resgatar as múltiplas experiências das mulheres e/imigrantes. Assim, reconhece-se a pesquisa empírica como elemento indispensável e, nesse sentido, valoriza-se o uso de uma diversidade de fontes, que constituem um mosaico de referências do passado. A dificuldade enfrentada pelo investigador está mais na fragmentação do que na ausência documental, requerendo uma paciente busca de indícios, sinais e sintomas, acrescida da análise detalhada para esmiuçar o implícito e o oculto, atentando para os múltiplos significados da documentação.

A busca dessas fontes deu-se em arquivos de São Paulo, Rio de Janeiro e na Europa (Portugal, Espanha e Itália), Arquivo Nacional do Rio de Janeiro, Arquivo do Estado de São Paulo Deops (Departamento de Ordem Política e Social), Memorial do Imigrante de São Paulo, arquivos de empresas e outros mais, englobando fontes censitárias, cartas, prontuários, depoimentos e memórias, imprensa diária e operária, fontes empresariais, entre outras.

\section{Mulheres e o trabalho no campo: cafeicultura, núcleos coloniais e culturas de subsistência}

Na última década do século XIX, um novo perfil populacional em São Paulo, transformado pelo intenso fluxo imigratório, abrangeu mudanças em relação à presença feminina no universo do trabalho nas cidades e no campo.

No setor agrícola, o trabalho feminino sempre foi uma constante. Na virada do século XIX para o XX, 80\% da força de trabalho agrícola estava empregada na cafeicultura, sob o sistema de colonato (que persistiu até os finais da década de 1950) (STOLCKE, 1986, p. 54). Uma amostra da presença feminina neste regime pode ser aferida por meio de um censo realizado em 1907 no município de São Carlos, localizado no eixo de expansão da Paulista, no centro do estado: do total de 18.493 mulheres presentes no município, $76 \%$ (14.125) habitavam o meio rural. Destas, o contingente feminino com idade mínima de 12 anos somava 8.199 mulheres, das quais 7.394 declararam profissão, sendo impressionante que, deste universo, 5.546 (nada menos que 75\%) eram colonas (RECENSEAMENTO, 1907).

No sistema de colonato os fazendeiros contratavam as famílias que deveriam arcar com os cuidados do cafezal (mediante pagamento predefinido) e com as tarefas da colheita, que ocorria entre maio e agosto e era remunerada pela quantidade de sacas colhidas 0 chefe da família, que era quem recebia os ganhos e organizava o trabalho, mobilizava, alocava e coordenava as tarefas que eram, no entanto, fruto de um esforço conjunto de todos os 
membros da família (MARTINS, 1979; HOLLOWAY, 1986). O trabalho feminino era então normalmente caracterizado como ajuda ao trabalho masculino, o que determina sua invisibilidade, não obstante sua importância crucial para a subsistência e manutenção familiar.

FIGURA 2

Colheita de café na fazenda do coronel Schmidt (início do século XX) - Acervo Edgar Leuenroth

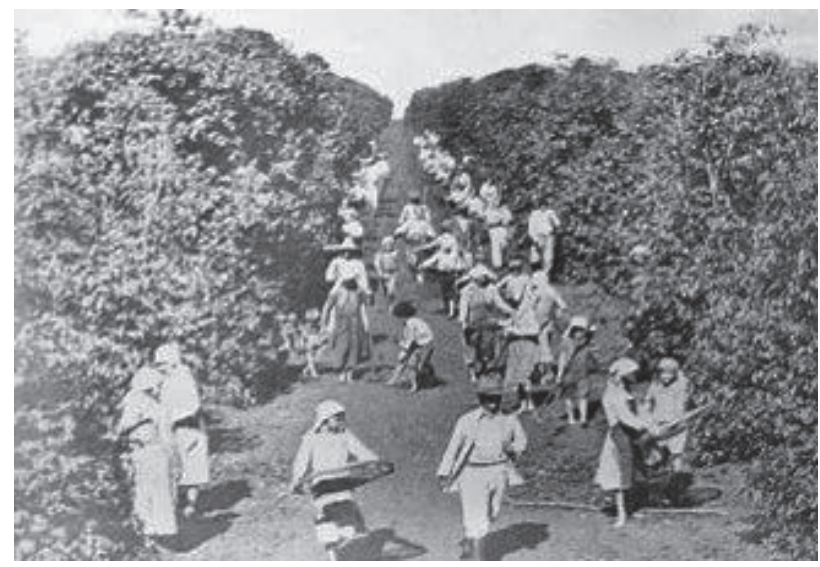

Mesmo ocultado, nas correspondências trocadas entre imigrantes aparecem menções frequentes ao trabalho feminino, como no caso desta fazenda do município de Tietê, a meio caminho entre Sorocaba e Piracicaba.

Estado de S. Paulo Tieté 11 de novembro de 1916

Querida Mulher

Participo te que estou trabalhando na fazenda Capoarinha em tieté no Estado de S. Paulo pertencente ao Sinor Osorio de Morães o qual me faz o favôr de mandarte vir para trabalhares aqui na lavoura junto comigo, por tanto é bom estares preparada para quando receberes 0 aviso poderes em barcar e assim juntos guilernaremos milhor a vida. Junto de nossos filhos. recebe saudades minhas deste teu marido. Manuel de Jasos Vieira (Carta Processo/maço 61759/0023, Arquivo Distrital do Porto/PT).

Nessa forma de organização de trabalho familiar, as mulheres desempenhavam papel crucial (STOLCKE, 1986. p. 14). Além de trabalharem no cafezal em tarefas como carpir/ limpar o café e outras atividades associadas, elas também se fizeram presentes, sobretudo, na colheita, enfrentando as agruras da empreitada, muitas vezes sem nada ficar a dever ao trabalho masculino, como no caso relatado nas proximidades de Rio Claro.

Oh! se trabalha. Tinha mulher lá, barbaridade. Eu tinha uma cunhada... ela desafiava qualquer homem na enxada... na colheita tem mulher que colhe mais... ela trabalha mais severa. (Depoimento de um colono da fazenda Santa Gertrudes) (BASSANEZI, 1999, p. 289-315)

Eram ainda as mulheres as principais encarregadas das lavouras de subsistência, nas quais se plantavam milho, mandioca e feijão, entre outros produtos. Elas também cultivavam 
a horta, criavam animais de pequeno porte, cuidavam das vacas e cavalos, preparavam carnes, faziam embutidos e produziam banha e sabão, farinha, conservas, doces, queijos e manteiga - o conjunto dessas ações cotidianas garantia custos mais reduzidos de manutenção e qualidade da vida familiar:

Às mulheres, no período do colonato, atribuía-se o trabalho no cafezal, o trabalho na casa, a educação dos filhos, os cuidados com o quintal, a horta de subsistência, buscar água nas minas e buscar lenha; e aos homens o trabalho no cafezal ou como diarista, quando esse fosse o caso. As mulheres tinham, assim, uma jornada justaposta, enquanto os homens uma jornada única de trabalho [...] Nos relatos das antigas trabalhadoras da Fazenda Jatahy observou-se essa maior quantidade de trabalho, que era realizada por elas. Havia uma fusão entre espaço e tempos femininos, desaparecendo a dicotomia fora/dentro de casa. (ANDRIOLLI, 2006, p. 109-111)

Assim, "evidencia-se que não havia divisão público/privado do espaço, tampouco do tempo; as tarefas produtivas e reprodutivas sobrepunham-se" (ANDRIOLLI, 2006, p. 104), tanto para as casadas quanto para as solteiras, ambas submetidas às exigências da dominação patriarcal e do trabalho, fosse este doméstico, fosse este no cafezal, para onde não raramente carregavam junto as crianças pequenas.

Nos depoimentos de mulheres que trabalharam nesta antiga Fazenda Jatahy, localizada no município de Luiz Antonio, na região de Ribeirão Preto, observa-se que

[...] o marco temporal utilizado por elas foi a maternagem, realizada tanto pelas mães, quanto pelas filhas. À época em que ainda eram filhas, o pai e a mãe iam ao cafezal acompanhados, se fosse o caso, pelos filhos homens em idade de trabalhar. A filha mais velha dentre as mulheres ou dentre todos os filhos ficava na casa, cuidando dos irmãos menores. Quando a menina adquiria a idade para o trabalho no cafezal (10 a 12 anos) ia no lugar de sua mãe. A mãe voltava, então, para a casa, para os trabalhos domésticos, os afazeres do quintal, as criações e a maternagem. A filha, entretanto, além de realizar o trabalho no cafezal, ao retornar à casa auxiliava a mãe nas atividades domésticas e na maternagem. (ANDRIOLLI, 2006, p. 97-98)

Não era incomum que mulheres, assim como os homens, também se acidentassem no trabalho das lavouras:

Sao Carlos, 7 de Novembro de 1909

Tenho-lhe a dar-le a mais grande fatalidade que aconteceu na familia pelo fallecimento de Mamãi no dia 24 do passado, em consequencia da mordedura de uma jararacussú foi mordida quando estava colhendo café no braço esquerdo durou 8 dias soffrendo muito mais o que devemos fazer do impossivel nada tem que fazer, depos que o $\mathrm{Sr}$ foi daqui do Brazil a familia tem sido uma fatalidade, mais esta ultima foi a mais grande que perdamos uma mamãi. Alfredo (Carta 469, Acervo Hospedaria dos Imigrantes/Apesp, 1909).

Por vezes, infortúnios familiares agravavam a situação de jovens mulheres ainda não saídas da infância. Após a morte da mãe (1918), Amélia, o pai e quatro irmãos menores migraram para a América. Depois de uma rápida passagem por Buenos Aires, juntaram-se aos avós em São Paulo e seu pai foi trabalhar na fazenda Santa Veridiana, em Araras, 
município servido por um dos ramais da Companhia Paulista. Ela rememorou que, com dez anos de idade, cuidava de todos:

Começou a minha luta de dona de casa, sempre lembrando das palavras da minha santa mãe. Cozinhava, lavava, passava e tinha que ir buscar lenha no mato junto com outras mulheres. Elas tinham pena de mim e me ajudavam a cortar a lenha, fazer os fechinhos e por na minha cabeça para trazer para casa. A noite eu fazia uma polentinha para de manhã tomar com café porque na fazenda não tinha padaria e nem pão. Assim, dava para tapear o estômago. Eu catava a roupa junto numa bacia de lata e ia lavar no rio donde tinha pedra, donde esfregava a roupa. Eu ficava com os pés na água até metade das pernas. Depois torcia, punha na bacia e punha na cabeça e trazia para casa. Estendia daquele jeito na cerca que dava no fundo do quintal. Depois ia buscar água na bica com a canga aqui no pescoço. Trazia duas latinhas de três litros de cada lado. A bica ficava distante de casa. Perto de casa tinha uma família muito grande, tinha um casal de velhos, tinha dois filhos casados e moravam diversos netos. Todos trabalhavam na fazenda. Eles tinham muita pena de nós. Presenciaram a nossa vida, sem mãe e sem experiência nenhuma. Então, os velhinhos e as noras matavam porco, faziam pão em casa, me chamavam na cerca e me davam sempre alguma coisa, me orientavam como temperar a comida e me davam muita força e coragem... agradeço a Deus de ter encontrado uma família que soube nos confortar e dar tanto carinho. [Depoimento de D. Amélia, aos 86 anos] (SANTOS, 1994, p. 31-54).

Segundo o que apurou Leite (2001, p. 132),

As mulheres eram avaliadas como boas ou más donas de casa. A dona de casa era o baluarte da família, responsável pela empresa doméstica e sua prosperidade. Não apenas era responsável pela sobrevivência, educação e saúde dos membros da família, como pela transmissão das tradições nacionais ou religiosas e da celebração adequada dos rituais familiares e comunitários. Uma de suas mais sérias atribuições e que era vista como uma virtude era a de casar as filhas, sobrinhas, e até vizinhas devalidas, levandoas a ocupar um papel significativo na comunidade. A casa era uma unidade de produção e consumo. Em inúmeras delas nasceram escolas e não eram poucas as que dedicavam os serões ao acabamento de malharias e confecções.

As mulheres mantinham ainda a responsabilidade pelos afazeres domésticos (cozinhar, lavar, passar, limpar) e cuidados com as crianças. Filha de colonos italianos mantovanos chegados ao Brasil em 1891 e logo instalados no oeste paulista, Oringa recordou a incansável atividade de sua mãe, Adele Rossi, no cotidiano rural, mesmo após a família já ter logrado se instalar como proprietária de terras:

Um outro trabalho que nós, as filhas, temos que fazer com todo o cuidado para não ter que desmanchar e fazer de novo, é a costura das roupas. O corte ela acompanha de perto, para que não se perca o pano, ainda mais quando a roupa é cara. Na sala fica a tábua onde estão os seis cabides para dependurar as camisas do pai e dos irmãos. Mas nenhuma camisa é passada e vai para o cabide, sem que a mãe verifique se não há um botão frouxo, ou um furo que precisa ser remendado [...] E completa: a preguiça é a mãe de todos os pecados. Acho que é por pensar assim que eu nunca vi a mãe parada, sentada num canto sem fazer nada. Está sempre mexendo com alguma coisa, mesmo que seja aquela em que ninguém está pensando, como ajeitar melhor uma vara no galinheiro, examinar os progressos da última ninhada da carijó, ou os leitõezinhos de cria do chiqueiro menor, 
ou, ainda, verificar se regamos a horta na medida certa, se não está faltando esterco nos legumes. E não se passa um único dia sem que ela vá cuidar do seu recanto predileto da horta [...] A mãe nunca tem pressa de se livrar do serviço, mas se aflige, porque, com tanto o que fazer, não é sempre que pode atender os gostos de cada um na comida: para um o ovo é mais duro, para outro é mais molinho, a sopa de feijão um quer com arroz, outro com macarrão, a macarronada com mais ou menos tempero, a carne de porco mais gorda... mais magra..., o refogado de berinjela só com sal e cebola, ou com um pouco de pimenta, ou ardido de arrancar água dos olhos... (TELAROLLI, 1991, p. 108-110)

A importância destas funções na jornada cotidiana foi também lembrada nas cartas de chamada escritas por maridos portugueses aflitos com a ausência das esposas, como esta escrita em Colina, município servido pela Companhia Paulista cujos trilhos desde 1912 já alcançavam Barretos, no centro-norte do estado:

\section{Colina 29 de Agosto de 1916}

Minha estimada mulher emprimeiro logar estimo tua saúde como é fim é noça filha que boa esta nuca me (ilegivel) esquecidas que minha é boa graças a Deus. Para sempre enriqueta lembras que te mando cem mil rreis para bires para minha companhia e mais noça filha que eu já estou cançado de cozinhar e lavar que istou sozinho [...] Recomendas e meu pai i mãe i tu ve se desse resposta desta carta (Carta Processo/maço 61757/18/19/20, Arquivo Distrital do Porto/PT).

Apesar de uma árdua rotina e da importância para a sobrevivência e alimentação da família, o trabalho feminino era desprestigiado também na sua conceituação. Assim, as funções masculinas eram definidas como "serviço de gente" (eram remuneradas ao chefe da família apesar de serem fruto do esforço coletivo) e as atividades femininas eram denominadas de "trabalho para a gente" (STOLCKE, 1986).

Por fim, em muitas ocasiões eram as próprias mulheres colonas que comercializavam os produtos excedentes da horta e das criações nos povoados mais próximos. Referindo-se a duas irmãs casadas com dois irmãos, todos italianos, Aurelio Benedini recorda-se das atividades de sua mãe e sua tia, no primeiro sítio que conseguiram comprar no município de São Joaquim da Barra, próximo a Franca, em 1906, 18 anos após a chegada ao Brasil:

Os homens sempre na lavoura de milho e as mulheres, revezavam-se, uma na cozinha, outra na enxada, alternadamente. Quando chegavam em casa, sua tarefa era cuidar de todas as crianças, cozinhar, passar, remendar para as duas famílias, que viviam na mesma casa como se apenas uma família fosse. Durante todo o tempo que os dois casais, Evaristo-Ezilia e Attilio-Zaira, residiram em suas terras de São Joaquim da Barra, o divertimento das duas irmãs era criar os filhos e, aos domingos, vestidas com as melhores roupas, faziam um passeio à cidade de São Joaquim, cada uma com uma bacia com ovos de galinha, colocadas sobre a cabeça e, caminhando à pé alguns quilômetros, vendiam os ovos para particulares. Com o dinheiro apurado, compravam botões, colchetes, carretéis de linha, agulhas e mais utilidades domésticas, sempre dentro da receita do dia. Certa vez, aos 8 anos de idade, ouvi de um conhecido da família que as duas irmãs se revezavam nas obrigações e também na gravidez, quando uma amamentava, a outra estava em gestação. À noite, as duas se juntavam, as crianças eram banhadas no córrego ou em uma bacia. A casa era limpa e arrumada. Na época da colheita do milho, de novo 
as duas participavam do trabalho manual, despalhando, debulhando, limpando o milho, preparando-o para ser comercializado e também para o consumo da casa e dos animais domésticos. (BENEDINI, 1999, p. 33-4)

Apesar de ocultadas e até desprestigiadas, são constantes as referências de que, entre as famílias migrantes nas quais as mulheres estiveram presentes, as possibilidades de saúde e prosperidade da família foram muito maiores. Tanto no caso das atividades agrícolas como nas cidades. Daí as ocasiões relativamente frequentes em que foram postumamente louvadas nas biografias construídas com o intuito de enaltecer trajetórias familiares bem-sucedidas (TELAROLLI, 1991; BORSARI, 2012; BENEDINI, 1999).

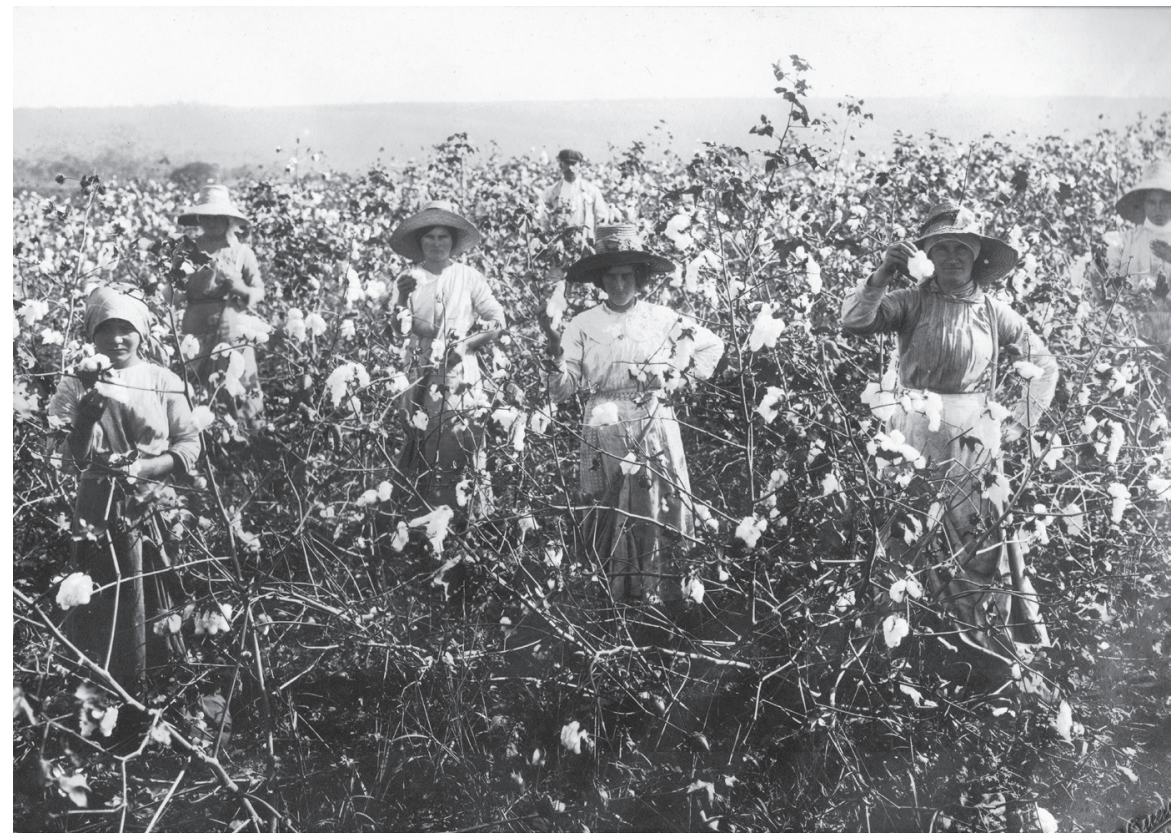

\section{Nas cidades: comerciando, hospedando, lavando, amamentando e tecendo nas indústrias do interior paulista}

Além da capital, a indústria se expandiu nos interiores paulistas, arregimentando um número significativo de trabalhadores, incluindo crianças e mulheres, que atuavam em diferentes setores. Merecem menção alguns casos privilegiando as cidades de Sorocaba e Araraquara, a título de exemplo.

O surgimento do parque industrial têxtil de Sorocaba teve início com a implantação da Fábrica de Fiação e Tecidos Nossa Senhora da Ponte (conhecida também como Fábrica Fonseca 1881), acrescentando-se a esta outras empresas, como Fábrica Santa Maria (1882), 
Votorantim e Santa Rosália (1890), Companhia Nacional de Estamparia (CNE, 1909) e a Fábrica Santo Antônio (1913), todas caracterizadas por grandes estruturas fabris, que inclusive abrigavam vilas operárias.

Na fiação e tecelagem, as mulheres perfaziam cerca de $75 \%$ do total da mão de obra empregada ${ }^{4}$ em diferentes funções (carreteleiras, fiandeiras, tecelãs, passadeiras, empacotadeiras), com expressiva participação de imigrantes e preferencialmente de jovens. 0 cotidiano do trabalho era árduo, em ambientes insalubres, com jornadas extensas (de 12 a 15 horas diárias), muitas vezes sem descanso semanal, sendo que eventualmente podia acontecer o "serão", quando o trabalho era estendido até a madrugada. Outro aspecto denunciado pela imprensa operária eram os abusos que as mulheres sofriam no ambiente de trabalho, vindos dos seus administradores, mestres e contramestres. Este é o caso da Fábrica Fonseca, na qual um contramestre fez "propostas indecorosas" a uma operária, e seus companheiros nada fizeram em seu favor, revelando "uma falta de ação dos camaradas" (CARMO, 2007, p. 11).

0 jornal $O$ Operário também denunciava que as mulheres trabalhavam e produziam em quantidade igual à dos homens, mas seu ordenado representava apenas $65 \%$ do masculino adulto. Assim sendo, baixos salários, tarefas rotineiras, repetitivas, monótonas e menos qualificadas na hierarquia laboral caracterizaram o emprego das mulheres nas indústrias.

Além da fiação e tecelagem (algodão, seda, juta e lã), a presença feminina foi também detectada no setor de vestuário, confecções de roupas, camisas, malharia, produção fabril de redes, fitas, bordados, meias, tamancos, chapéus e alimentos (massas, biscoitos e chocolate), além de atuarem na manufatura de cigarros, charutos e fumos, tocador, fósforos, velas e sabão. Exemplar é o caso da Fábrica de Meias Lupo de Araraquara (fundada em 1921, para a produção de meias masculinas) que utilizava basicamente mão de obra feminina, com expressiva presença de imigrantes.

As folhas de pagamento da época mostram: a maioria das empregadas eram italianas e filhas de italianos. Henrique Lupo [...] relacionava-se com todos e era natural o instinto de proteção em relação a seus compatriotas: ele sabia da associação do produto com a delicadeza, considerada atributo feminino, fez com que esse mercado de trabalho se caracterizasse como excelente para esse tipo de mão de obra. As mulheres sempre foram percebidas como mais adaptáveis a este tipo de trabalho. Consideradas portadoras de qualidades como destreza, habilidade manual, delicadeza, cuidado. Ocupavam na fábrica de meias funções ligadas ao processo produtivo, que começava com a preparação do fio, passando pela tecelagem até o acabamento. Na fábrica, as funções exercidas pelas mulheres, sempre ligadas à produção de meias, eram: operadoras de máquinas, texturização, preparação do fio, remalhadeiras, repassadeiras, bordadeiras, costureiras, separadeiras de punhos, auxiliares de acabamento, mensageiras etc - trabalhos parcelares e rotineiros - podendo uma minoria alcançar posições mais elevadas como líderes de turnos, ajudantes de encarregadas, chegando no máximo à encarregada

\footnotetext{
${ }^{4}$ Em 1912, dos 10.204 operários recenseados pelo Departamento Estadual do Trabalho de São Paulo, 6.801 eram do sexo feminino (BOLETIM, 1911, p.76-7).
} 
geral de seção. Apesar das habilidades exigidas para a entrada neste mercado de trabalho (bordar, costurar, fazer crochê e tricô), o trabalho de confecção de meias exigia aprendizagem. No início, as moças que iniciavam nas atividades da fábrica ainda muito jovens, entre 14 e 17 anos e mesmo aquelas mais maduras, recebiam treinamento no próprio processo de trabalho, para o que foi contratada uma profissional especializada. (CAIRES, 2015, p. 34)

As possibilidades e estratégias de ações aparecem exemplarmente referendadas nas memórias de D. Amélia.

Em 1921, nós morava aqui na Rua Sete/Araraquara. Eu queria ter meu dinheirinho. Aí foi quando comecei a lavar roupa pra fora: cobertor, tudo. Um mil réis a dúzia... um mil réis a dúzia! Já tava cansada, com treze anos. Aí passei a me comunicar com essa amiga, Ercília, pelo quintal. Ela disse: "Amélia, você quer trabalhar? Vamos palitar cadeira, assento 54 de cadeira?" Então fazíamos assento, dois, três por dia para ganhar alguma coisa. Chegou um dia, ela falou assim: “Cansou!” Aí disse: “Vamos procurar outra coisa?” Aí eu procurei, aqui na Rua Cinco, a fábrica de alfinetes. Nós fomos lá, as duas e trabalhava o dia inteiro. Fazia alfinete por quilo! Até que cansamos: "Amélia, então vamos dar outro jeito." Eu sempre com ela. Entre 1921 e 22 fomos na fábrica de Palamone que era lá embaixo, que é onde é a Caixa Econômica agora, depois do jardim e tinha a fábrica de biscoito, de bala, de bolacha, tudo. Me empreguei eu com ela lá. Então eles faziam a bolacha champagne, com saquinho e a bolacha maizena e embrulhávamos balas a quilo. Nós íamos embrulhando e ganhando nosso dinheirinho. Vai que nesse meio, apareceu esse negócio do Lupo. (SANTOS, 1994, p. 31-54)

Pesava na opção por empregar mulheres o fato de elas possuírem como atributos delicadeza, submissão, paciência, cuidado e docilidade. ${ }^{5} \mathrm{~A}$ imposição da disciplina de fábrica refletia a própria posição social em que estavam inseridas as mulheres: a subordinação à autoridade do marido, pai e irmãos que se reproduzia no meio fabril numa subserviência ao mestre e ao contramestre. Esta situação cotidiana e a imagem idealizada da submissão, no entanto, não impediram momentos de combatividade e enfrentamento. ${ }^{6}$ Encontram-se evidências documentais e a historiografia ressalta que as mulheres participaram ativamente nas lutas operárias e nos movimentos grevistas. Contudo, essas manifestações apresentaram formas diferenciadas e, em geral, não resultavam de uma prática sindical contínua, sendo que sua organização possuía peculiaridades, era mais espontânea, circunstancial, efêmera e vulnerável. As mulheres atuaram com frequência em movimentos pela redução da jornada de trabalho e, mormente nas ocasiões de redução de salário, reagiram também às condições de trabalho que lhes eram impostas: maus tratos, repentinas diminuições de tarifas, aumentos de jornadas, multas e assédio sexual.

\footnotetext{
$\overline{5}$ Em Sorocaba, a fabricação de tecidos e malharia era a atividade industrial mais importante, seguida da produção de alimentícios, bebidas e vestuário (CARMO, 2007).

${ }^{6}$ Para análises históricas sobre as resistências e combatividade feminina na capital paulista, ver Rago (1985) e Moura (1982).
} 


\section{Trabalho domiciliar}

0 trabalho domiciliar, apesar da sua baixa remuneração, foi importante alternativa para as mulheres por permitir conciliar os encargos de mãe e de dona de casa (trabalho doméstico) com funções que thes proporcionavam algum rendimento. ${ }^{7}$ Analisando o já mencionado Censo de 1907, realizado no município de São Carlos, observou-se que alguns trabalhos realizados pelas mulheres residentes na área urbana ocorriam no âmbito domiciliar. Dentre as profissões desenvolvidas pelas mulheres imigrantes de etnias diversas, verificou-se que, entre as italianas, espanholas e portuguesas, a profissão predominante das mulheres era costureira, seguida de lavadeira; já para as "turcas" (na verdade, sírias e libanesas), a profissão das mulheres aparece influenciada pela de seus respectivos maridos que eram negociantes e mascates (RECENSEAMENTO, 1907). O trabalho domiciliar feminino era atividade realizada nas próprias residências para empresas, oficinas ou intermediários, no regime de pagamento por peça. Este foi intensamente utilizado para os chamados trabalhos de agulha, tais como costura, bordados, tricô, crochê, consertos em geral, confecção de roupas, enxovais de cama e mesa, lingerie, chinelos, chapéus, flores e também para a "costura de carregação" de produtos, como sacos de juta para o café e uniformes fabris.

Estas ocupações foram abraçadas por mulheres imigrantes não só por conta das dificuldades de inserção no mercado de trabalho, mas também por opção de não se empregar numa função regular, com horário fixo e jornada determinada. Contudo, a possibilidade de trabalhar em casa não significava escapar às exigências de prazos e de controle de qualidade impostas pelos contratantes.

No caso da Fábrica de Meias Lupo de Araraquara, ${ }^{8}$ além da presença feminina no espaço fabril, também eram realizadas por meio de trabalho domiciliar as tarefas de fechamento das meias e do bordado da baquete nas laterais das meias (realizado à mão). A função de baqueteira envolvia um elevado número de mulheres na cidade de Araraquara, na sua maioria imigrantes, só deixando de existir nos finais da década de 1950, quando foram incorporadas novas máquinas que também faziam esses detalhes nas meias (SANTOS, 1997). Mesmo pouco visível, um número expressivo de mulheres atuava nos denominados trabalhos “de agulha”. Sua qualificação era feita por meio do processo de socialização e da educação, ou seja, as mulheres utilizavam no trabalho habilidades aprendidas com outras mulheres ao longo de suas vidas. Destreza, rapidez, repetição e precisão eram elementos importantes para a execução de bordados e costura, muitas dessas ocupações eram transmitidas de geração a geração.

Vai que nesse meio, apareceu esse negócio do Lupo. Veja quanto que nós trabalhamos! De 1921 a 24 passamos todas essas fábricas para poder ganhar alguma coisa. Até meu pai, às

\footnotetext{
${ }^{7}$ Sobre trabalho a domicílio, consultar Abreu e Sorj (1993).

${ }^{8}$ Organizada inicialmente na residência de seu fundador-proprietário, instalada em área central de Araraquara, a produção possuía apenas duas máquinas e o trabalho era realizado por sua própria família - esposa e filhos em idade de trabalhar.
} 
vezes, ficava bravo. “Quero ganhar, quero trabalhar!” Queria vestir minhas irmãzinhas e queria meu dinheiro. Aí fomos na meia Lupo. Foi quando estourou isso aí, que é a fábrica de meia Lupo. Simples meia Lupo, começou com oito máquinas usadas, trazidas de São Paulo. A senhora do dono, agora não me lembro o nome... Matilde, parece que ela se chamava, que veio ensinar a pôr a agulha. Até meu casamento trabalhei na fábrica, para depois trabalhar em casa como baqueteira, por muitos anos. (SANTOS, 1994, p. 31-54)

FIGURA 4

Interior de seção da fábrica de meias Lupo (década de 1930) - Acervo Meias Lupo

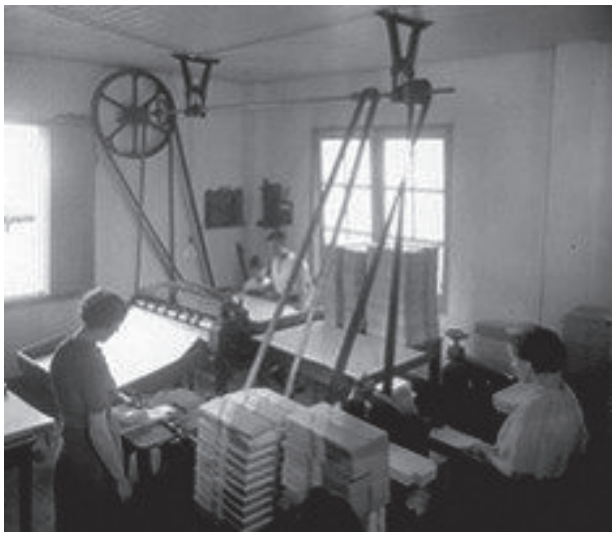

\section{Entre panos, sacos e cestos: a presença feminina no comércio}

O aumento considerável da população urbana nos interiores gerou novas oportunidades para o crescimento das atividades comerciais e de abastecimento. No setor de gêneros alimentícios, ampliaram-se os estabelecimentos de pequeno e médio portes, bem como 0 comércio de produtos variados, tecidos, utilidades, armarinhos entre outros. ${ }^{9}$

Procurando trabalhar com um custo operacional mínimo, inúmeras famílias aproveitavam o quarto da frente de suas próprias casas para estabelecer pequenas lojas, armarinhos e armazéns de secos e molhados, açougues, adegas, quitandas de frutas e legumes, vendas, bar, botequins. A participação de mulheres nesses negócios era determinante, entrecruzando o público e o privado: a mulher administrava o lar e o negócio, trabalhando de madrugada a madrugada no balcão, dedicando-se, junto ao marido, aos negócios familiares. Vários desses estabelecimentos eram, inclusive, conhecidos pelos nomes de suas proprietárias e, dessa forma, a história do pequeno comércio nos interiores não pode ser escrita exclusivamente no masculino.

Longe de estarem recolhidas ao lar, as mulheres imigrantes se fizeram presentes no espaço público, como pode ser comprovado por algumas trajetórias. No caso da imigração

\footnotetext{
${ }^{9}$ As mulheres casadas e solteiras não podiam registrar em seu nome negócios e estabelecimentos, tendo como exceção as viúvas, que gozavam de certa autonomia, podendo assumir os registros e as responsabilidades na condução de negócios e encabeçando empreendimentos.
} 
de origem síria e libanesa, por exemplo, o papel das mulheres, embora ocultado, não pode ser menosprezado, podendo-se observar como foi decisiva sua presença nos negócios e na estruturação do cotidiano familiar. No Brasil, foi mais rara a presença de mulheres mascateando, já que a cultura patriarcal dos sírios e libanese ${ }^{10}$ condicionava as mulheres ao lar ou aos negócios familiares. Evidentemente havia um nicho na mascateação para as mulheres. Basta rememorar o relato de um antigo mascate: ao bater "à porta de certas casas e se as mulheres estivessem sozinhas, sem os homens que tinham saído para trabalhar, alguém de dentro respondia ‘aqui não tem ninguém”” (DRUBI, 1998, p. 71).

Havia, entretanto, exceções notáveis. Podem-se observar trajetórias femininas pelo depoimento de quatro irmãs provenientes do Líbano: Chahine, Mentaha (Amélia, no Brasil), Julia e Salime.

Julia era trabalhadeira [...] era esperta. Já chegou aqui e começou a trabalhar [...] Veio com 16 anos, começou a mascatear em Dois Córregos. Levava um empregado, alguém que carregasse a mala. Ela ia a pé. Depois, quando começou a ganhar dinheiro, comprou um trole e mascateou em trole durante muito tempo.

Ganhou dinheiro e se estabeleceu, montou loja de tecidos e roupa feita, em Jaú, onde estava a melhor freguesia... ficou viúva muito moça, ela também não dava muita confiança para o marido nos negócios, ela é quem tocava tudo... Ela ia para o Rio fazer compras [...] Tinha a melhor loja de Jaú. Trazia de tudo do estrangeiro para todos os brasileiros, trazia roupa feita... ela tinha muita personalidade...

Na época da crise do café, uma mulher naquela idade, fumava, usava saia-calça e chapelão e percorria a divisa da fazenda a cavalo. Uma das primeiras mulheres que fumaram em Jaú foi Julia... ela era conhecida por Julia Turca... um dos primeiros proprietários de automóvel em Jaú foi ela. E depois, embora ela tivesse aquela loja muito grande e bonita, comprou uma fazenda (GREIBER et al., 1998, p. 277-83).

Nesse processo, Júlia chamou as irmãs para Jaú. Salime montou um armazém em frente à loja da irmã; outra irmã, Amélia, depois de casada, se estabeleceu em Bocaina, numa loja de fazenda, de beira de estrada e era ela quem ficava lá vendendo.

As trajetórias dessas irmãs tornam-se exemplares: Júlia mascateou, montou loja, ficou rica e comprou fazenda; as outras três tocavam seus negócios, duas delas mesmo sendo casadas, o que mostra sua autonomia, empreendedorismo e o papel central que desempenharam.

Da mesma forma, a presença da mulher nos negócios é destacada em outras memórias femininas de imigrantes sírio-libanesas.

\footnotetext{
$\overline{10}$ Este grupo apresenta uma cultura patriarcal fortemente arraigada. Muitos sírios e libaneses vieram para o interior paulista munidos da intenção de trabalhar, angariar certo montante de recursos e retornar à terra natal, na sua maioria vieram solteiros ou, mesmo casados, vieram desacompanhados de suas esposas e filhos. Tal condição lhes permitia uma maior mobilidade, sobretudo tendo-se em vista a ocupação inicial de mascate, abraçada por contingentes expressivos deste grupo étnico. Ocorre que o plano inicial nem sempre era cumprido; já com a perspectiva de se fixar, seguia-se a necessidade de se casar. Era comum ir à terra de origem para "arrumar" esposa, ou sondar, mesmo à distância, as moças disponíveis. A maior parte dos casamentos na época era arranjada pelas famílias. Depois de acumular certo pecúlio com a mascateação, o passo seguinte era se estabelecer com uma loja. Para que esta prosperasse, era melhor contar com o apoio de uma família, inclusive para trabalhar na loja (TRUZZI, 2008).
} 
Eu me criei em Presidente Alves, lá me criei, lá me casei. Fica para lá de Bauru [...] Papai dizia: "Você pode ajudar sua mãe no meio da semana, mas no sábado e domingo tem que trabalhar na loja até às três horas da tarde". Às vezes, quando o movimento estava bom, ficava aberta até às sete horas [...] Era pesado o serviço da loja. Eram aquelas peças de tecido, pesadas, 60, 70 quilos, eu era magrinha, ficava cansada. Eu pesava 42 quilos, quando me casei, eram aqueles sacos de açúcar de 60 quilos, farinha de trigo de 70 quilos, eu punha no chão, abria, naquele tempo não era empacotado, era vendido por quilo, por arroba... fui criada ali, eu gostava. (GREIBER, 1998, p. 277-83)

Outras mulheres de várias nacionalidades atuavam no comércio de rua como ambulantes, comercializavam em carrocinhas e cestos produtos como verduras, legumes, frutas, flores, ovos, batatas, cebolas, aves, carnes, peixes, leite, pão, frangos, entre outros. Algumas vendas eram eventuais, como a oferta de um excedente disponível ou sobras da produção de quintal. ${ }^{11} \mathrm{Em}$ muitos casos, a atividade era regular, como a das verdureiras, na sua maioria imigrantes, que vendiam em feiras livres o que produziam em chácaras existentes nos arredores das cidades. Relembra Angela Opido Alegria:

Aí, meu pai tinha um terreno muito grande onde ele plantava verdura. A minha mãe, ela enchia a cesta de verduras e ia vender, sabe. E ela tinha muita freguesa de roupa. Quando ela ia, ela ia carregada de verdura, assim, para vender. Quando ela voltava, ela vinha carregada aquela cesta cheia de roupa para lavar. Minha mãe, coitadinha, às vezes... mas ela trabalhava demais, sabe. [Depoimento de Angela Opido Alegria ao Museu da Imigração do Estado de São Paulo, 2007]

Percorrendo cotidianamente um roteiro determinado, as leiteiras, majoritariamente italianas, visitavam a freguesia com seus animais (vacas e cabras), oferecendo leite retirado na hora. Tal prática persistiu até que passou a ser questionada pelas medidas de normatização do leite higiênico, que buscavam controlar a qualidade do leite, e a atividade foi se reduzindo até a sua extinção.

Nos domicílios, exímias cozinheiras faziam doces, salgados e petiscos comercializados pelas ruas em bandejas e cestas; algumas adquiriram clientela fixa e produziam regularmente quitutes sob encomenda. Havia ainda as que forneciam refeições diárias e as que transformavam suas residências em pensão, experiência que também fez parte da trajetória de D. Amélia em Araraquara.

E depois de um tempo a gente passou apertado. 0 dinheiro era pouco. A Rosária tava começando a costurar. Eu cheguei a dar pensão pra sete moças. Amontoei num quarto, me pus a dormir no chão com meu marido. Meu marido ficava bravo: "Você vai se sacrificar a esse ponto?” Era estudante, era tudo da escola. Dormiam e eu dei as camas melhor pra elas dormir. Porque eu também ganhava umas coisinhas. Elas gostavam da minha comida, aquela macarronada que eu fazia! Os pais eram fazendeiros. Traziam leitoa e eu colocava aqueles tachos de macarronada, assim e comia tudo! (SANTOS, 1994, p. 31-54)

\footnotetext{
${ }^{11}$ Contudo, os rendimentos dessas atividades eram incertos, sujeitos à sazonalidade e aos efeitos das intempéries naturais como geadas, chuvas, granizos e seca. A atividade de venda de verduras podia ser uma forma de complementação da renda familiar e incluía-se entre os encargos domésticos o cuidado com a horta. Como ambulantes eventuais, podiam comercializar os excedentes, estando presas às flutuações do excedente disponível, das sobras da produção para consumo próprio.
} 
No acervo do Deops/SP, ${ }^{12}$ entre os imigrantes investigados, foram pesquisados os prontuários de mulheres portuguesas, espanholas e italianas, destacando-se entre os motivos de averiguações os pedidos de autorização para funcionamento de casa de cômodos, pensão e hotéis $(32 \% \text { dos casos })^{13}$ e querelas entre proprietárias e inquilinos (15\%). Estas questões vinculam-se à significativa presença das imigrantes como proprietárias de pensão e casas de cômodo, já que esta era uma das várias estratégias de sobrevivência, uma possibilidade de fonte de renda com o aluguel de um cômodo, um quarto anexo ou pequeno imóvel. ${ }^{14}$

\section{Serviços domésticos}

Os serviços domésticos eram outro tipo de atividade que absorvia um amplo contingente de mulheres imigrantes, com várias possibilidades: empregadas, cozinheiras, lavadeiras, passadeiras, engomadeiras, arrumadeiras, governantas, roupeiras, copeiras, pajens, babás e amas-de-leite. 0 já aludido recenseamento realizado em São Carlos em 1907 indica que, no meio urbano, pelo menos 44\% das mulheres de no mínimo 12 anos de idade que declararam profissão o fizeram como cozinheira, copeira, lavadeira, engomadeira, criada ou empregada (RECENSEAMENTO, 1907).

A ampliação da participação dos imigrantes nos serviços domésticos se insere num quadro de transformações do mercado de trabalho. 0 processo imigrantista construiu um discurso que valorizava o imigrante como "civilizado, honesto, ordeiro, limpo, sincero e pacífico", constituindo um perfil ideal para essas funções.

Algumas se empregavam ainda meninas, como foi o caso de D. Amélia em Araraquara:

Ali me empreguei numa alemã para limpar a casa (com doze anos, hein!), a casa e a cozinha. Ganhava dez mil réis por mês... dez mil réis por mês! E quando recebi, comprei um par de sapato por dez mil réis. (SANTOS, 1994, p. 31-54)

\footnotetext{
$\overline{12}$ As origens do Deops são encontradas no Gabinete de Investigações, organizado por Washington Luís no período em que era secretário estadual de Justiça e Segurança Pública de São Paulo (1909). Quando assumiu a prefeitura da cidade de São Paulo (1914-1919), ele buscou consolidar o aparato policial para enfrentar as manifestações sociais, particularmente as greves operárias. Já como presidente do Estado (1924), Washington Luiz criou delegacias especializadas, entre elas a que investigava as ameaças à ordem pública: instituía-se o Deops, com a preocupação de vigiar e controlar as ditas "classes perigosas". Para possibilitar melhores identificações, o novo aparelho recebeu do patronato paulista milhares de fichas com informações sobre os trabalhadores engajados, grande parte oriunda das "listas negras". Contando com uma rede de colaboradores e com monitoramento diário, na função de fiscalizar e reprimir, este órgão funcionou entre 1924 e 1983. Somente a partir 1996 é que os seus documentos foram abertos à consulta pública. 0 acervo de mais de 160 mil prontuários e 9 mil dossiês (cooperativas, sociedades, clubes, círculos, escolas, sindicatos, partidos, etc.) encontra-se acessível ao pesquisador no Arquivo do Estado de São Paulo.

${ }^{13}$ Visando um controle sobre as práticas de lenocínio e para garantir o perfil familiar das pensões, havia exigências legais de controle destes estabelecimentos.

${ }^{14}$ Seguem alguns exemplos de solicitação de autorização para hotel e pensão, recolhidos entre prontuários no Deops: Maria da Silva Cruz (Prontuário 120731, portuguesa)/Quatá; Maria dos Santos (Prontuário 4728, portuguesa)/Campinas; Maria Vieira Teodósio (Prontuário 70105, portuguesa)/Sorocaba; Matilde Chaves Câmara (Prontuário 126948, portuguesa)/ Oswaldo Cruz; Teresa Beltrami (Prontuário 71769 italiana)/Itatiba; Philomena Barbison Scabelo (Prontuário 100041, italiana)/ Matão; Joaquina de Souza Priaro (Prontuário 85757, portuguesa)/Botucatu; Leopoldina Rosa Mendes (Prontuário 107657)/ Dourado; Tereza de Jesus Ribas (Prontuário 115730, portuguesa)/Presidente Prudente; Julia Pereira Fernandes (Prontuário 103998, portuguesa)/Presidente Prudente; Felicíssima dos Pantos (Prontuário 101259, portuguesa)/Presidente Prudente; entre outros.
} 
Em algumas situações, as famílias se empregavam unidas: a mulher nos serviços domésticos, enquanto os homens exerciam serviços de jardinagem e horta, faxina interna e externa, cuidados com os animais domésticos ou atuavam como cocheiros. Na maioria dos casos, moravam na casa dos patrões, se livrando dos gastos com comida e aluguel, mas mantinham-se disponíveis todos os dias e horários.

As criadas enfrentavam uma rotina doméstica árdua e cansativa, começavam a trabalhar desde a madrugada e, dependendo das necessidades, só paravam altas horas da noite, ficando à disposição para serviços eventuais. Enfrentavam rígido programa de afazeres, com funções estabelecidas para o dia e distribuídas pela semana. As práticas se diferenciavam de casa para casa, sendo que algumas eram dirigidas de forma rígida outras mais flexíveis. $\mathrm{Na}$ árdua rotina interpenetravam-se tarefas variadas e de certa forma sobrepostas, em geral realizadas longe da presença de outros membros da família, apesar do controle das patroas, como um serviço invisível e desprestigiado, apesar de indispensável. ${ }^{15}$

Numa residência com muitos empregados havia rigorosa hierarquia e delimitações de funções. A copeira, além do serviço de mesa, era encarregada dos cuidados com as louças, cristais e prataria. As governantas e preceptoras (na maioria alemãs, por sua suposta autoridade e dinâmica de trabalho, ou francesas, pelo refino) eram também empregadas em casas de viúvos e solteiros, ou em famílias que desejassem delegar a responsabilidade sobre os demais criados.

Todavia, o mais comum era uma única empregada que realizava todos os serviços: limpar, lavar, engomar, cozinhar e arrumar. As mais experientes faziam verdadeiros malabarismos para executar todas as suas obrigações, que também incluía o trato do galinheiro, horta, pomar e até vendas ocasionais de excedentes desses produtos.

Os trabalhos na cozinha eram contínuos e árduos. Cozinhava-se no fogão de lenha, o que exigia habilidades não apenas na elaboração dos pratos, mas também com o uso do equipamento. As práticas alimentares transformaram-se consideravelmente com a chegada dos imigrantes (houve a introdução de práticas, gostos e sabores), a alimentação ficou mais variada e, correlativamente, as tarefas de preparação tornaram-se maiores. Os serviços na cozinha ocupavam o dia todo, preparavam-se refeições completas, com cardápios variados. Além do preparo do alimento (abate, limpeza e preparação de aves e animais de pequeno porte), os serviços de cozinha incluíam fazer pão, pilar e moer o milho e o arroz, pilar, torrar e moer o café, refinar o açúcar e o sal, preparar a banha, defumar carnes e fazer sabão.

Parentes mais pobres ou recém-chegadas do estrangeiro eram empregadas como domésticas, algumas ainda meninas com 10 ou 12 anos.

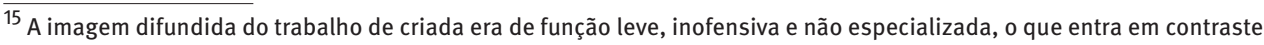
com as informações fornecidas pelos Boletins do Departamento Estadual do Trabalho, que revelam elevado número de acidentes de trabalho, apesar dos dados não expressarem a totalidade das vítimas, já que muitas deixavam de ser socorridas, adoeciam e chegavam a ficar incapacitadas.
} 
15 de julho de 1920

Minha querida Mai

Em primeiro logar o que eu mais dezeijo e que esta minha carta a vá encontrar de uma perfeita e felis saúde que a nossa é boa graças a Deus.

Minha mai recebi a sua carta dia 13 do corrente onde vim coanto me dizia pois onde fiquei mais satisfeito foi em me dizer que estava de saúde e com bontade e corajem de me vir vezitar e abraçar pois isso para mim será uma alegria e satisfação vira passar algum tempo de alegria e descanço se Deus quizer.

Com respeito a criada eu the fins siente na outra carta que lhe escrevi que seija uma rapariga seria e soçegada e trabalhadeira é para ficar empregada a qui em casa e em coanto aos rapazes se não over um rapas novo veja se pode arranjar um ou dois de uns trita a quarenta annos deçes dos lados de mega que seijão serios e respeitadores e trabalhadores se não souberem ler nem escrever não fas mal tambai são para ficar empregados com migo é para tratarem de lavoura o Alvaro sabe como eu os quero por que ele já foi meu empregado e já sabe as condições da caza e se não podér arranjar nem criada nem criados vem boçemeçe com a molher do João Marques que é a Dna Libramento. (Carta Processo/maço A000942X, Arquivo Distrital do Porto/PT, grifo nosso)

0 tratamento dado aos criados era variado, desde patroas que pagavam regular e pontualmente, forneciam casa, comida e auxílio em caso de doença, até aquelas que não pagavam nada, fornecendo apenas casa e comida, ocorrendo, ainda, situações em que as empregadas dormiam nos corredores e ladrilhos da cozinha, andavam sujas, malvestidas e subnutridas. As patroas concentravam as decisões sobre suas criadas, oscilando entre o exercício de repressão direta, exploração e paternalismo. Além do próprio serviço e horário de trabalho, chegavam a determinar se deveriam ou não sair às ruas, não sendo poucas as denúncias à polícia de confinamento e maus tratos nos espaços domésticos.

\section{Lavadeiras}

A lavagem de roupa era uma função essencial em qualquer moradia. As famílias de posses usavam grande quantidade de roupa branca no seu cotidiano (roupas de cama, mesa e banho) e também as vestimentas de homens, mulheres e crianças, que em geral exigiam cuidados especiais no lavar, passar e engomar. Difundiu-se assim a prática de dar roupa para lavar fora de casa, o que se casou com o esforço das mulheres imigrantes em trazer mais recursos monetários para a família.

As lavadeiras conheciam técnicas e os segredos de sua ocupação, estratégias para branquear, engomar e passar a roupa, além de produzirem elas próprias o sabão e a goma. Como a maioria das casas não possuía uma fonte direta de água, a lavagem ocorria em geral ao ar livre, ainda muitas vezes sob a interferência das condições climáticas adversas, como frio, chuva e garoa que dificultavam a execução do trabalho e da secagem, além de provocar atrasos nas entregas. 


\section{Amas de leite}

Uma das ocupações femininas que possibilitava melhores ganhos era a de ama de leite. Embora algumas mães não pudessem amamentar, outras não o faziam por costume, vaidade e falta de paciência. 0 ganho mais elevado, se comparado com outras funções, devia-se à responsabilidade de cuidados com os bebês, também porque esse serviço requeria paciência, dedicação e asseio constante, já que as amas tinham que manter a criança e a si própria limpas, requerendo constantes e generalizadas trocas de roupa, em geral toda vez que amamentavam.

Encontram-se menções nas cartas (de diferentes nacionalidades) com orientação para a vinda visando o exercício da função de ama de leite, destacando esta ser bem lucrativa. Nas missivas dizia-se que se enviava dinheiro para passagem e um excedente para comprar uma cabra, deixar o bebê com a avó e vir para São Paulo, cuidando para durante a viagem bombar o peito, para chegar com leite abundante. No caso da colônia italiana, reproduzia-se, no novo contexto da imigração para os interiores de São Paulo, a prática já tradicional das amas do Vêneto, que sazonalmente (a cada parto) se deslocavam para amamentar os filhos das elites do império austro-húngaro.

\section{FIGURA 5}

Ama de leite italiana (sem identificação de data) - Acervo Museu da Imigração Italiana/Roma

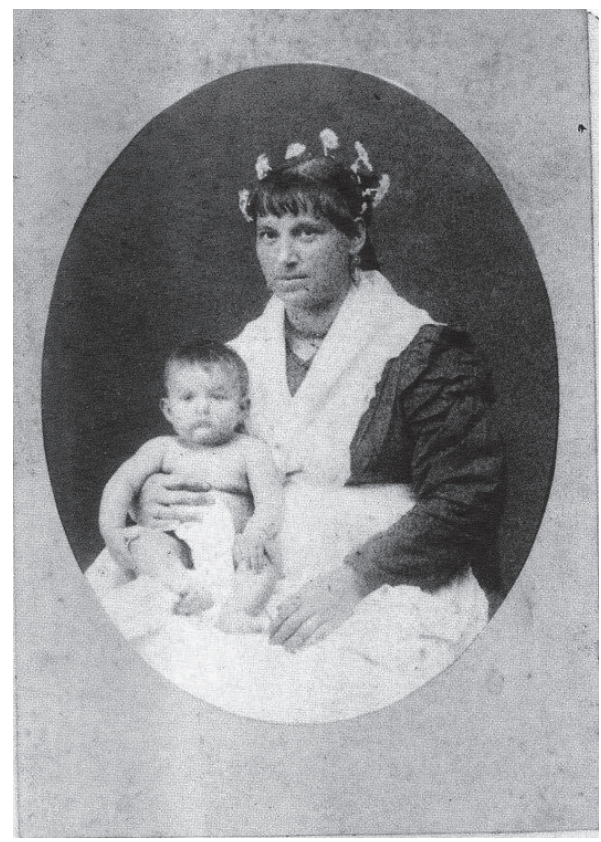

Os patrões atentavam para a possibilidade de as amas infectarem as crianças, principalmente com tuberculose e sífilis. Nesse sentido, a questão do aleitamento mercenário preocupava não só os pais, mas também as autoridades médicas que faziam advertências e 
tentavam regulamentar a ocupação. As ações de controle do aleitamento mercenário foram implementadas paralelamente à propagação de uma nova noção de maternidade (importância do aleitamento materno) e também pela difusão da puericultura, englobando princípios de dietética infantil que incluíam as campanhas pelo leite higienizado (pasteurizado).

\section{Considerações finais}

Para rastrear as experiências femininas nos processos de imigração nos interiores de São Paulo, enfrentam-se dificuldades de recuperar histórias que englobaram simultaneamente processos de participação e de exclusão. As imigrantes se fizeram presentes no controle da economia doméstica, educação dos filhos, manutenção das tradições, apesar de nem sempre exercerem uma profissão; elas trabalharam ativamente no campo e nas cidades, nas fazendas de café, nos núcleos coloniais, nas atividades fabris, comerciais e outras funções nos domicílios e nas ruas. Foram inúmeras e variadas as atividades em que essas mulheres atuaram e até se destacaram, entretanto, nem todas puderam ser aqui incorporadas, como, por exemplo, professoras, enfermeiras, parteiras, entre várias outras.

Buscou-se dar visibilidade às imigrantes enquanto agentes de transformação, destacando suas formas criativas de resistências e lutas, suas estratégias de sobrevivência e capacidade de improvisação, ações na busca de melhor condição para si e para a família, enfrentando um cotidiano árduo. Apesar de mantidas nas sombras, elas desempenharam papel ativo no cotidiano de trabalho e negócios, participando das decisões familiares, tornando-se fundamentais para o sucesso do projeto familiar de imigração e contribuindo para que as famílias tivessem maiores possibilidades, prosperassem e conseguissem melhor qualidade de vida e de saúde.

Não obstante os esforços de pesquisa, as experiências femininas se mantêm pouco focalizadas (abrindo um campo de possibilidades), mesmo diante de suas ações e importância como guardiães das tradições (religiosidade, sabores e receitas, saberes e cuidados, canções e gestos) e das histórias de terras distantes que povoaram a infância de muitos descendentes.

Por outro lado, essa investigação não se limita ao esforço de apontar possibilidades de dar visibilidade às mulheres imigrantes. Mais do que isso, se propõe a abrir horizontes metodológicos para os estudos dos deslocamentos, questionando o imigrante universal masculino e destacando a importância de se observar a experiência migratória a partir de uma diversidade de fontes e de outros olhares que valorizem a experiência feminina.

A análise sobre a noção de invisibilidade das mulheres imigrantes em outras sociedades contribui para observar que tal condição as torna vulneráveis a uma série de violações em matéria de direitos humanos (BROOKS; GELDEREN, 2016). Por sua vez, a contrapartida - positiva - da invisibilidade "é a pessoa ser reconhecida socialmente como alguém, no sentido de ser apreciada ou cuidada, de lhe serem atribuídos direitos, de ser tratada como igual ou de ser aprovada por ser o que é ou o que faz" (CARLEHEDEN; HEIDGREN; WILLIG, 2012, p. 1). 
Observando o uso muitas vezes impreciso do termo "invisível” na literatura acadêmica, tem-se buscado aprimorar analiticamente esta categoria, ao explorar os mecanismos que invisibilizam sujeitos históricos e apontando que eles podem se referir a três ordens distintas - cultural, legal e espacial - que não raramente se sobrepõem. Cada uma destas esferas pode obscurecer a circunstância de uma determinada experiência ter sido efetivamente realizada, o que determina sua desvalorização. Desse modo, ao esmiuçar o que designou como “mecanismos de invisibilidade”, Hatton (2017) propõe uma categoria analítica passível de ser aplicada na presente investigação.

Situações que recorrentemente silenciam ou tornam invisíveis as presenças femininas acabam abrangendo as três ordens acima referidas: cultural, porque as especificidades culturais e históricas, sobretudo em sociedades de cunho patriarcal das quais a maior parte dos imigrantes proveio, “naturalizam” a dominação masculina e uma visão de mundo falocêntrica, ocultando sua própria arbitrariedade (BOURDIEU, 2010, p. 149); legal, porque em muitas ocasiões aqui observadas, como por exemplo quando se trata de oficializar contratos de colonato, era o homem, na época considerado o chefe da família, que tomava a frente e, como as mulheres tenderam a deixar poucos vestígios diretos, escritos ou materiais, há uma espécie de silêncio das fontes (PERROT, 2007, p.17); e espacial, porque as mulheres, como se observa em muitos casos, tenderam frequentemente a atuar sobretudo na esfera do doméstico-privado. Neste último sentido, a invisibilidade pode ocorrer "porque as mulheres são menos vistas no espaço público, o único que, por muito tempo, merecia interesse e relato. Elas atua[va]m em família, confinadas em casa, ou no que serve[ia] de casa" (PERROT, 2007, p. 16-17).

Por fim, não é demais ressaltar que a própria escrita da história por muito tempo ocorreu

[...] dentro de um sistema de valores masculinos que tomou certos acontecimentos, processos e movimentos como dignos de uma análise histórica e que excluiu ou ignorou outros por entender que são acessórios ou de incidência histórica nula [...] A mudança social costuma[va] situar-se na esfera pública ao mesmo tempo em que se ignora[va] $\mathrm{m}$ os processos, as instituições e os organismos relacionados mais diretamente com o indivíduo, isto é, a família, o casamento e as relações sociais interpessoais. (NASH, 1984, p. 17)

As histórias das mulheres imigrantes no interior paulista integram-se, assim, a uma ampla agenda de investigações que ainda está por ser cumprida.

\section{Referências}

ABREU, A. R. P.; SORJ, B. (Org.). 0 trabalho invisível. Estudos sobre trabalho a domicílio no Brasil. Rio de Janeiro: Rio Fundo Editora, 1993.

ALVIM, Z. Brava gente! Os italianos em São Paulo. 2. ed. São Paulo: Brasiliense, 1986.

ANDERSON, B. Nação e consciência nacional. Rio de Janeiro: Ática, 2008.

ANDRIOLLI, C. S. Nas entrelinhas da história, memoria e gênero: lembranças da fazenda Jatahy. 
2006. 227f. Dissertação (Mestrado em Ciências Sociais) - Universidade Federal de São Carlos (UFSCar/PPGCSo), São Carlos, 2006.

BASSANEZI, M. S. Mulheres que vêm, mulheres que vão. In: PINSKY, C. B.; PEDRO, J. M. (Org.). Nova história das mulheres no Brasil. São Paulo: Contexto, 2012. p. 169-193.

Família e imigração internacional do Brasil no passado. Estudos Históricos, Franca, v. 2, n. 6, p. 289-315, 1999.

BASSANEZI, M. S.; SCOTT, A. S.; TRUZZI, O.; BACELLAR, C. A. P. Atlas da imigração internacional em São Paulo 1850-1950. São Paulo: Edunesp/Fapesp, 2008.

BENEDINI, A. A história dos Benedini e dos Girardi no Brasil. Ribeirão Preto: Legis Summa, 1999. BOLETIM DO DEPARTAMENTO ESTADUAL DO TRABALHO/SP (1-2): 41 e 11 trimestre de 1911-12. p.76-77.

BORSARI, J. Antes que a memória apague... Jaboticabal: Multipress, 2012.

BOURDIEU, P. A dominação masculina. Rio de Janeiro: Bertrand Brasil, 2010.

BROOKS, K.; GELDEREN, T. Fighting invisibility: the recogniton of migrant domestic workers in the Nederlands. Humanity in Action, 2008. Disponivel em: 〈https://www.humanityinaction. org/knowledgebase/103-fighting-invisibility-the-recognition-of-migrant-domestic-workers-inthe-netherlands〉.

CAIRES, A. C. R. A Lupo em Araraquara: revivendo a memória, retecendo a história (1921 a 1980). Revista Uniara, v. 18, n. 1, p. 25-42, julho 2015. Disponivel em: 〈http://www.uniara.com.br/ legado/revistauniara/pdf/34/artigo_02.pdf〉. Acesso em: 24 jun. 2017.

CARLEHEDEN, M.; HEIDEGREN, C.; WILLIG, R. Recognition, social invisibility, and disrespect. Distinktion: Journal of Social Theory, v. 13, n. 1, p. 1-3, 2012.

CARMO, J. C. do. Industrialização sorocabana: classe operária, trabalho, organização do trabalho e educação (1882-1913). In: XXIV SIMPÓSIO NACIONAL DE HISTÓRIA. Anais... São Leopoldo-RS: ANPUH, 2007. Disponível em: 〈http://anais.anpuh.org/wp-content/uploads/mp/pdf/ANPUH. S24.0373〉. Acesso em: 03 abr. 2017.

DRUBI, S. Raízes de Jaborandi. Barretos: Soares Barretos Gráfica e Editora, 1998.

DUTRA, E. Crime político e segurança nacional. Seminários: Imigração, Repressão e Segurança Nacional, n. 3, p. 15, dezembro 2003.

GREIBER, B. L. et al. Memórias da imigração. Libaneses e sírios em São Paulo. São Paulo: Discurso Editorial, 1998. p. 244-68.

HATTON, E. Mechanisms of invisibility: rethinking the concept of invisible work. Work, Employment and Society, v. 31, n. 2, p. 336-351, Apr. 2017.

LEITE, M. M. Retratos de família. Leitura da fotografia histórica. São Paulo: Edusp e Fapesp, 2001.

MARTínEZ, E. E. G. O Brasil como país de destino para os migrantes espanhóis. In: FAUSTO, B. (Org.). Fazer a América. São Paulo: Edusp, 1999.

MATOS, M. I. S. de. Cotidiano e cultura. 2. ed. Bauru: Edusc, 2015.

Portugueses: deslocamentos, experiências e cotidiano SP séculos XIX e XX. Bauru: Edusc, 2013.

MOURA, E. B. 0 trabalho da mulher e do menor na indústria paulistana (1890 - 1920). Petrópolis: Vozes, 1982. 
NASH, M. (Ed.). Presencia y protagonismo. Aspectos de la historia de la mujer. Barcelona: Ediciones del Serbal, 1984.

PERROT, M. Minha história das mulheres. São Paulo: Contexto, 2007.

RAGO, L. M. Do cabaré ao lar: a utopia da cidade disciplinar (Brasil 1890-1930). Rio de Janeiro: Paz e Terra, 1985.

RECENSEAMENTO DE SÃO CARLOS DE 1907. São Carlos, 1907 (manuscrito).

SANTOS, L. dos. Recontando os pontos do bordado. Um estudo do trabalho a domicílio (Araraquara, 1934-1957). Cadernos CERU, São Paulo, v. 2, p. 113-129, 1999.

Trabalho domiciliar feminino nas indústrias de meias Lupo. Dissertação (Mestrado em Sociologia) - Universidade Estadual Paulista (Unesp), Araraquara. 1997.

Cadernos de Campo. Araraquara: Universidade Estadual Paulista (Unesp), 1994.

STOLCKE, V. Cafeicultura: homens, mulheres e capital (1850-1980). São Paulo: Brasiliense, 1986.

TELAROLLI, R. Os que dizem ‘addio’ não olham para trás. Edição familiar, 1991.

TRENTO, A. Do outro lado do Atlântico - um século de imigração italiana no Brasil. São Paulo: Nobel, 1989.

TRUZZI, O. Italianidade no interior paulista: percursos e descaminhos de uma identidade étnica (1880-1950). São Paulo: Ed. Unesp, 2016.

TRUZZI, O. Patrícios: sírios e libaneses em São Paulo. São Paulo: Ed. Unesp, 2008.

VANGELISTA, C. Os braços da lavoura. São Paulo: Hucitec, 1991.

Carta Processo/maço 61759/0023, Arquivo Distrital do Porto/PT.

Carta 469 acervo Hospedaria dos Imigrantes/APESP, 1909.

Carta Processo/maço 61757/18/19, Arquivo Distrital do Porto/PT.

Carta Processo/maço A000942X, Arquivo Distrital do Porto/PT.

Depoimento de Angela Opido Alegria - Museu da Imigração do Estado de São Paulo, 2007.

\section{Sobre os autores}

Maria Izilda Santos Matos é livre docente em História pela Pontifícia Universidade Católica de São Paulo (PUC-SP) e professora titular do Departamento de História dessa mesma instituição.

Oswaldo Truzzi é doutor em Ciências Sociais pela Universidade Estadual de Campinas (Unicamp) e professor titular no Programa de Pós-graduação em Sociologia da Universidade Federal de São Carlos.

Carla Fernandes Conceição é mestre em Sociologia pela Universidade Federal de São Carlos e doutoranda em Sociologia por esta mesma instituição.

\section{Endereço para correspondência}

\section{Maria Izilda Santos Matos}

Av. Cons. Rodrigues Alves, 804. ap. 141

04014-002 - São Paulo-SP, Brasil 


\author{
Oswaldo Truzzi \\ Rua Joaquim da Cruz Penalva, 833 \\ 13566-810 - São Carlos-SP, Brasil \\ Carla Fernandes Conceição \\ Av. Bruno Ruggiero, 101, casa 63 \\ 13562-420 - São Carlos-SP, Brasil
}

\begin{abstract}
Immigrant women: presence and concealment (São Paulo Provinces, 1880-1930)

This paper aims to shed new light on the female presence in the (im)migration process to the provinces of São Paulo state, approaching different aspects of the experiences, routine tasks, work activities and cultural background of immigrant women. To that end, several sources were evaluated and revised, including letters, working logs, statements, memory journals and articles from daily newspapers or labor press. The text seeks to give a context to the role of immigrant women, both in rural areas, focused in coffee agriculture, or in town areas of São Paulo, where they represent a significant presence in several urban occupations, local trade, industrial activities or domestic housework. In addition, the present paper suggests broadening methodological horizons to study dislocations, questioning the typical universal male figure in immigration studies, and highlighting the importance of facing the migration experience from other perspectives, including that of women.
\end{abstract}

Keywords: Women. Immigrants. Gender. Provinces of São Paulo.

\title{
Resumen
}

Mujeres inmigrantes: presencia y ocultamiento (Interiores de São Paulo, 1880-1930)

Este artículo busca dar visibilidad a la presencia femenina en el proceso de e/inmigración hacia el interior del estado de San Pablo, abordando aspectos diferenciados de las experiencias, acciones cotidianas, actividades de trabajo y background cultural de las mujeres inmigrantes. Para ello, se valora el uso y la relectura de cierta diversidad de fuentes que incluyen cartas, prontuarios, testimonios, memorias, prensa diaria y obrera, fuentes empresariales y registros censales, entre otras. El texto busca contextualizar el protagonismo de la mujer inmigrante tanto en el medio rural paulista, marcado por la expansión de la economía cafetalera, como en las ciudades del interior, en las cuales su presencia en los oficios urbanos, en el comercio, en la industria y en los quehaceres domésticos es marcada. Se propone además abrir horizontes metodológicos para los estudios de los desplazamientos, cuestionando el inmigrante universal masculino y destacando la importancia de observar la experiencia migratoria a partir de otras miradas, incluso el femenino.

Palabras clave: Mujeres. Inmigrantes. Género. Interiores de San Pablo. 